\title{
石炭焚発電プラント用高速 $\mathrm{NO}_{\mathrm{x}}$ 測定装置の開発 ${ }^{\dagger}$
}

\author{
四郎丸功 ${ }^{1} \cdot$ 秋山重之 $^{2+\dagger}$
}

\begin{abstract}
${ }^{1}$ 中国電力（株）火力発電技術センター, 759-0205 宇部市大字西沖の山字西沖 1-2
2 (株) 堀場製作所, 601-8510 京都市南区吉祥院宮の東町 2 番地
\end{abstract}

火力発電プラントでは，ボイラで発生した望素酸化物を脱硝装置で除去しており，脱硝装置の効率的な 運用や安定な運転のためには, 排ガス $\mathrm{NO}_{\mathrm{x}}$ 測定装置の応答速度の高速化が有効である. 著者らはこれまで サンプリングガス流量を増大させることにより，LNG 焚発電プラント用高速 $\mathrm{NO}_{\mathrm{x}}$ 測定装置を開発してき た.しかしながら, 石炭焚発電プラントにおいては, LNG 焚発電プラントとは異なり, 排ガスに多量のダ ストが含まれるため, 同様の手法で NOx 測定を高速化することは困難であった。本研究では, LNG 焚発 電プラント用高速 $\mathrm{NO}_{\mathrm{x}}$ 測定装置と同様に, サンプリングガス流量を增大させても高いダスト除去効率を 得ることのできるダスト除去システムを開発することにより，従来の $1 / 9$ の応答時間を持つ石炭焚発電プ ラント用高速 $\mathrm{NO}_{\mathrm{x}}$ 測定装置を実現し，運用中の石炭焚発電プラントにおいて，光の効果を確認した。

緒言

発電プラントにおける脱硝装置は，環境保全のための重要な排 ガス処理設備の一つである．脱硝装置は，触媒を充填した脱硝反 応器, アンモニア $\left(\mathrm{NH}_{3}\right)$ 注入量制御装置, アンモニア注入ノズ ルおよび $\mathrm{NO}_{\mathrm{x}}$ 測定装置等から構成されており，ボイラで発生した $\mathrm{NO}_{\mathrm{x}}$ 量に適したアンモニアを注入し，触媒によって $\mathrm{NO}_{\mathrm{x}}$ を無害 な $\mathrm{N}_{2}$ と $\mathrm{H}_{2} \mathrm{O}$ に分解している. 従って，ボイラの運転状態に応じ て変化する $\mathrm{NO}_{\mathrm{x}}$ 量に対して最適な $\mathrm{NH}_{3}$ 量を注入し安定した脱 硝制御を実現するためには, $\mathrm{NO}_{\mathrm{x}}$ の変化を高速に測定することが 重要となる (Denki Gijutsu Kijun Chosa Iinkai, 1989).

著者らは, $\mathrm{LNG}$ 焚発電プラントの脱硝装置用として, サンプル ガス流量を増大させることにより，サンプルガス採取ロから $\mathrm{NO}_{x}$ 測定セルまでのサンプルガスの通過時間を短縮させて応答時間を 大幅に短縮した $L N G$ 焚発電プラント用高速 $\mathrm{NO}_{\mathrm{x}}$ 測定装置を開 発した。そして，この装置を中国電力 (株) 柳井発電所 1 号および 2 号系列に適用し, 脱硝装置の効率的な運用や運転制御の安定化 に有効であることを実証してきた（Hirozane and Kondo， 1994).

一方，石炭焚発電プラントにおいても同様の目的で高速応答の $\mathrm{NO}_{\mathrm{x}}$ 測定装置が求められている(Ando, 1990)。しかし，石炭焚 発電プラントの排ガス中には, クリーンな LNG の排ガスと違っ て $20 \mathrm{~g} / \mathrm{m}^{3}$ 程度のダストが含まれており, LNG 焚発電プラント 用高速 $\mathrm{NO}_{\mathrm{x}}$ 測定装置と同样にサンプルガス流量を増大させると ダストを除くためのパージフィルタの目詰まりが急速に起こり， 排ガスのサンプリングの障害となって安定な $\mathrm{NO}_{\mathrm{x}}$ 測定が不可能 であった。

今回著者らは, LNG 焚発電プラント用高速 $\mathrm{NO}_{\mathrm{x}}$ 測定装置と同 様にサンプルガス流量を増大させてもパージフィルタの目詰まり を起こさないようにダストを除去する石炭排がス用のダスト除去 システムを新たに開発することにより，石炭焚発電プラント用高 速 $\mathrm{NO}_{\mathrm{x}}$ 測定装置の実現に成功した。

† 1999 年 5 月 10 日受理

†† akiyama @ horiba.co.jp
1. LNG 焚発電プラント用高速 $\mathrm{NO}_{\mathrm{x}}$ 測定装置の応答性向上対 策

発電プラントにおける脱硝装置の概略を Fig. 1 に示す。脱硝装 置入口および出口には $\mathrm{NO}_{\mathrm{x}}$ 測定装置が設置されており,ボイラで 発生する $\mathrm{NO}_{\mathrm{x}}$ 量が測定され, 安定した脱硝制御が実現されてい る.

Fig.2(a) は著者らが開発した LNG 焚発電プラント用高速 $\mathrm{NO}_{\mathrm{x}}$ 測定装置の概略を示しており，この高速 $\mathrm{NO}_{\mathrm{x}}$ 測定装置では， $\mathrm{NO}_{\mathrm{x}}$ 測定装置の応答時間の 8 割程度がサンプリング系 (配管, 粗 フィルタ, サンプリングポンプおよびサンプルガス除湿器等で構 成される）をサンプルガスが通過する時間で占められている. LNG 焚用高速 $\mathrm{NO}_{\mathrm{x}}$ 測定装置では，その通過時間を短縮させるこ と，すなわち，サンプルガスがサンプリング系を経て $\mathrm{NO}_{\mathrm{x}}$ 測定セ ルに至るまでの時間を短くすることにより， $\mathrm{NO}_{\mathrm{x}}$ 測定装置の $90 \%$ 応答時間 $T_{90}$ (サンプルガス取込用のサンプリングプローブ出ロ 部から校正がスを吸引させて分析計の安定指示值の $90 \%$ に達す る時間で, むだ時間 $t_{\mathrm{d}}$ と $90 \%$ 上昇時間 $t_{90}$ の和 $t_{\mathrm{d}}+t_{90}$ と定義す る）を従来の $1 / 10$ に短縮させた.

ここで,サンプルガスがサンプリング系を経て $\mathrm{NO}_{\mathrm{x}}$ 測定セルに 至るまでの時間は，サンプリング系部品の全容積 $V$ を流量 $Q$ の サンプルガスで置換する時間 $t$ であり，次式（1）で与えられる. $t=V / Q$

Eq. (1) によると, サンプリング系の全容積 $V$ を小さくする か， $Q$ を増大させれば，置換時間 $t$ を短くすることができ，LNG 焚発電プラント用高速 $\mathrm{NO}_{\mathrm{x}}$ 測定装置では, 従来のサンプルガス流 量 $Q$ を $3 \mathrm{l} / \mathrm{min}$ から $20 \mathrm{l} / \mathrm{min}$ にすることで $t$ を短くして高速応 答を実現した。なお， $20 \mathrm{l} / \mathrm{min}$ という流量は，サンプリング流量 増加にともないサンプリング配管の圧力損失が増大し，容量の大 きなサンプリングポンプが必要になることから，装置全体の経済 性を考慮して決定した。

\section{2. 現状の石炭焚発電プラント用 $\mathrm{NO}_{\mathrm{x}}$ 測定装置のダスト対策}

一般的な石炭焚発電プラントの排ガスには, $20 \mathrm{~g} / \mathrm{m}^{3}$ 程度の夕 ストが含まれており，このダストがサンプルガスに多く含まれる とサンプリング系の詰まりの原因になったり，サンプリングポン 


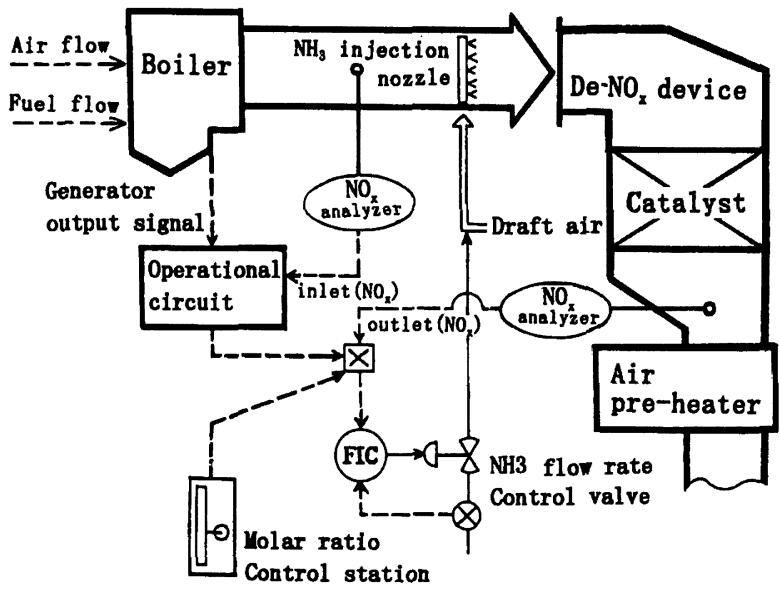

Fig. 1 NOx removal process for thermal electric power plants

(a) $\mathrm{NO}_{\mathrm{x}}$ analyzer system for LNG-fired plant

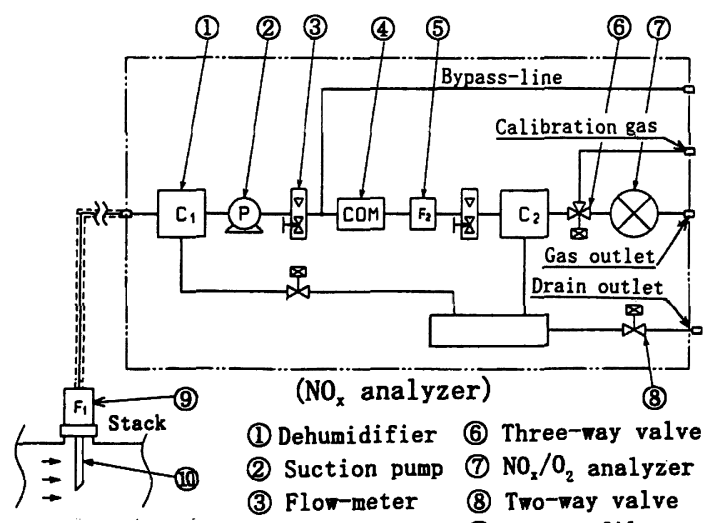

LNG fired flue gas (4) $\mathrm{NO}_{\mathrm{z}}$-converter (9) Coarse filter

(5) Fine filter (10) Sampling probe

(b) $\mathrm{NO}_{\mathrm{x}}$ analyzer system for coal-fired plant

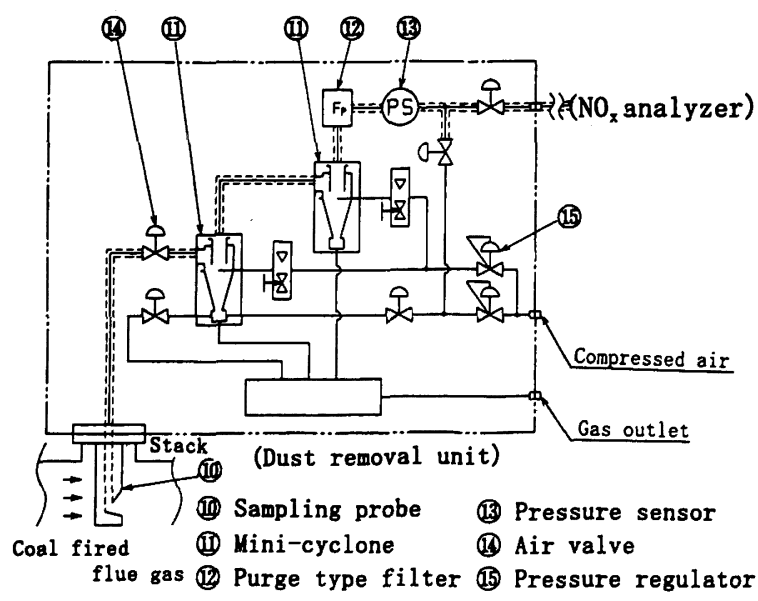

Fig. 2 Sampling flow diagram of high response $\mathrm{NO}_{\mathrm{x}}$ analyzers for LNG and coal-fired plant

プや $\mathrm{NO}_{\mathrm{x}}$ 測定セル等に悪影響を及ぼし， $\mathrm{NO}_{\mathrm{x}}$ の正常な連続測定 を妨げる。

このため, 従来の $\mathrm{NO}_{\mathrm{x}}$ 測定装置では, サンプリング系に, $2 \mu \mathrm{m}$ メッシュのステンレス製フィルタと, フィルタの目詰防止のため に圧力 $0.5 \mathrm{MPa}$ の空気で定期的にフィル夕を逆洗するパージ機 構を組み合わせたパージフィルタを設けてダストを除去している

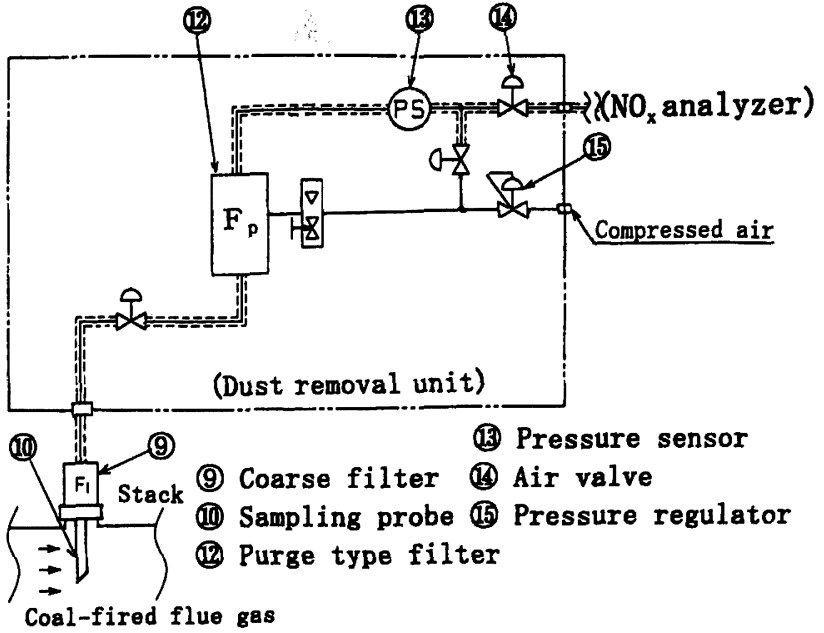

Fig. 3 Sampling flow diagram of conventional $\mathrm{NO}_{\mathrm{x}}$ analyzer for coal-fired plant

Number of days [ day ]

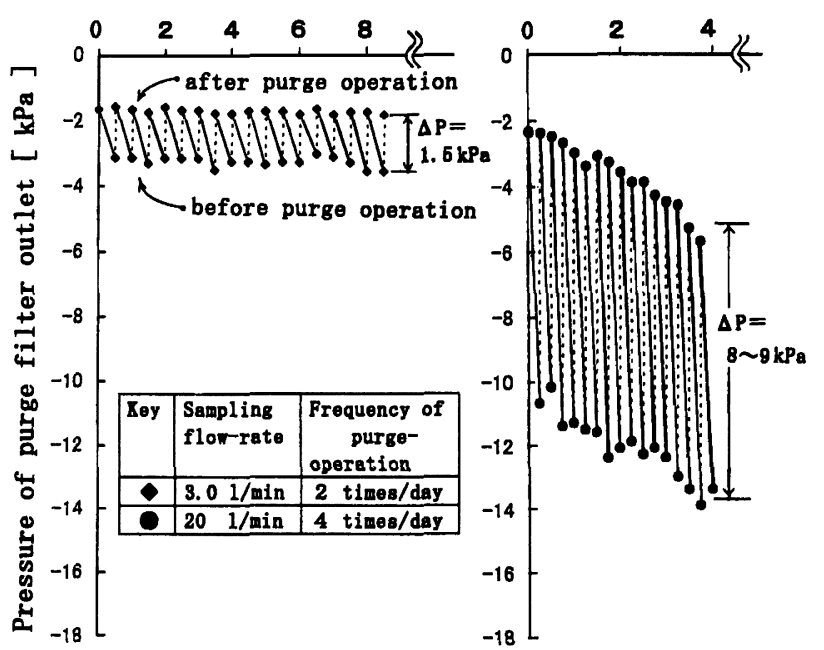

Fig. 4 Change of pressure loss of purge type filter for coalfired plant

(Fig. 3 参照).

この逆洗操作においては，目詰まりの量がある限度を超えると 逆洗効果が薄れ，ダストがフィルタ内に徐々に蓄積し，フィルタ を元の状態に戻すことができなくなる. そのため, 逆洗操作の運 用は，フィルタの目詰まりの程度をフィルタの出入口の圧力差 $(\Delta P)$ で監視して (Ito et al., 1995), フィルタの逆洗効果が保て るうちに逆洗を行っている（実際の $\mathrm{NO}_{\mathrm{x}}$ 測定装置では， $\Delta P$ は フィルタの目詰まりの程度を測定するためにのみ用い, 逆洗操作 は一定時間おきの簡単な制御により行っている).

これまでの運用から, 従来の石炭焚発電プラント用 $\mathrm{NO}_{\mathrm{x}}$ 測定装 置では, フィルタの圧力差が約 $1.5 \mathrm{kPa}$ (フィルタ出口圧力は 3.5 $\mathrm{kPa}$ 程度）に達した時に逆洗を行えば, 目詰まりが増大すること なく, $\mathrm{NO}_{\mathrm{x}}$ 測定装置は連続して正常に動作することを確認してい る. そしてその時の逆洗回数は, 発電プラント型式や炭種による ダストの量, 粒度の違いによって異なるが, 一般的には, 2〜3 回/ 日であった（Fig. 4 参照）。

\section{3. 石炭焚発電プラント用 $\mathrm{NO}_{\mathrm{x}}$ 測定装置の応答性の改善に対す る課題と解決策}

$\mathrm{NO}_{\mathrm{x}}$ 応答速度を速くするため, サンプルガス流量を增大させる 


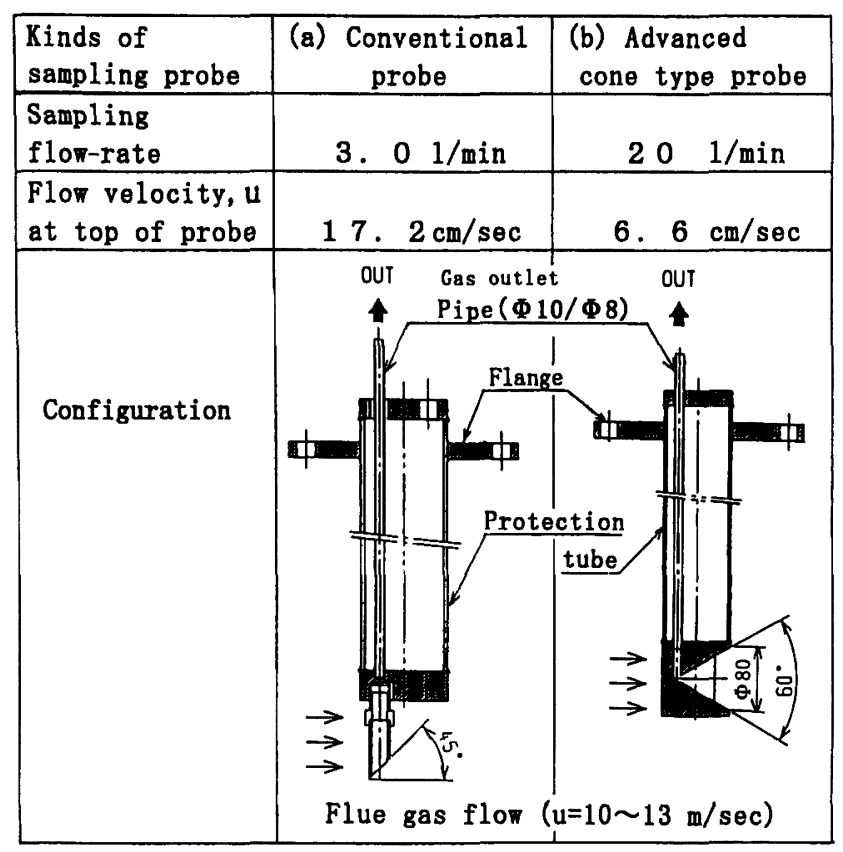

Fig. 5 Configuration of sampling probes

ことが有効であることは前述した通りである。しかし，従来の石 炭焚発電プラント用 $\mathrm{NO}_{\mathrm{x}}$ 測定装置においては, ダスト除去システ ムとしてパージフィルタしか持っておらず, $\mathrm{NO}_{\mathrm{x}}$ 測定高速化のた めにサンプルガス流量を增大させると，フィルタ差圧は 6 時間程 度で8 9 $\mathrm{kPa}$ に上昇し(フィル夕出口圧力は $10 \sim 11 \mathrm{kPa}$ ), 短時 間で逆洗効果の限界を超之, $\mathrm{NO}_{\mathrm{x}}$ 測定装置の連続測定が不可能で あった (Fig. 4 参照).

この課題を解決するためには，多くのサンプルガス流量を確保 してもサンプルガスのダストをフィルタの入口で逆洗効果が保て る程度に除去できるダスト除去システムの開発が必要である。ま たあわせて，今回の開発では，より高速なサンプリング系を構成 するために，パージフィルタの改良を試みた。

\section{4. ダスト除去システムの開発}

開発したダスト除去システムは，高いダスト除去効率を得るた めに, Fig. 2(b)に示すように, コーン型サンプリングプローブと 小型サイクロン，そしてパージフィルタを組み合わせた構造とし ている，以下に，開発したダスト除去システムの各部の概要を示 す.

\section{1 コーン型サンプリングプロープ}

従来のサンプリングプローブはFig. 5(a) に示すように先端部 は水平または角度 $45^{\circ}$ にカットされており，ダスト除去効率 $\eta$ は $90 \%$ 程度であるが, より高いダスト除去効果を得るために, Fig. 5(b) に示すコーン型サンプリングプローブ (以下，コーン型プロ ーブという）を採用した。 このサンプリングプローブは, 開口部 がコーン型であるため, サンプリングプローブ入口の開口面積が 大きくサンプル流速が遅くなっており，また排がスの流れと逆方 向からのサンプリングを行っているため, 多ト持ち込み量が減 少するという特徵を持っている (Iinoya, 1973; Makino et al., 1995).これを利用してダスト除去効果の改善を行うことができる と考えた.

\section{2 小型サイクロン}

サンプリングプローブの改良に加えて，多スト除去効率をさら

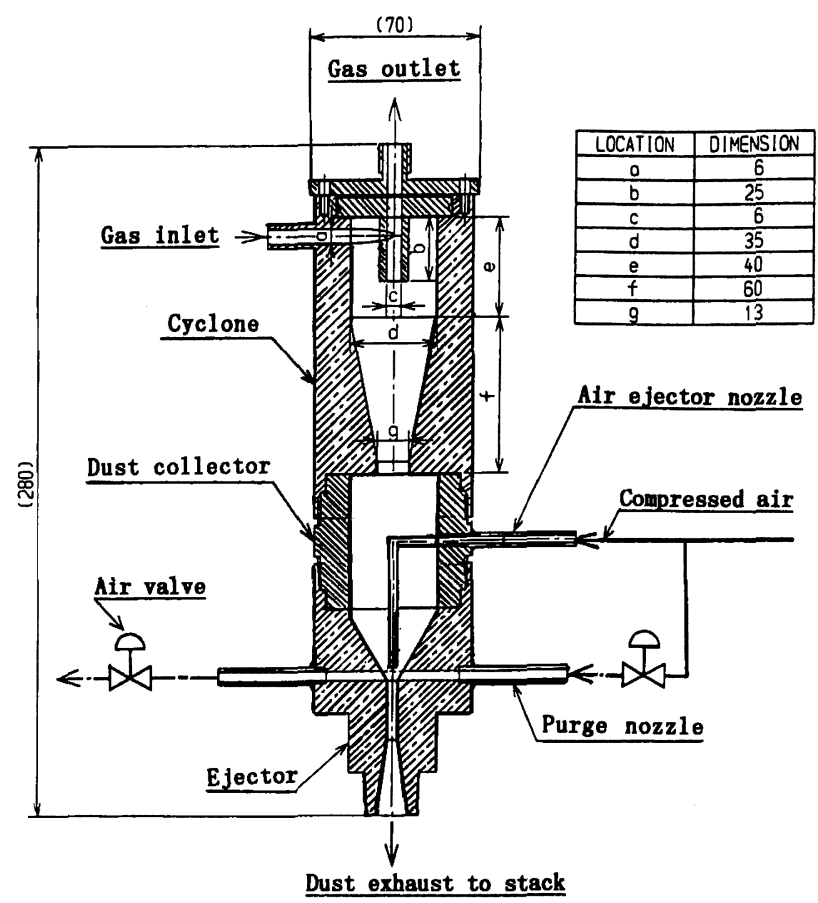

Fig. 6 Detail of mini-cyclone

に高めるために，コーン型プローブ出ロにダスト除去システムを 付加することを検討した。

従来, 一般的なダスト除去システムとしては, サイクロン, $\mathrm{EP}$, バグフィルタ, ベンチュリスクラバ，慣性集塵機などがある が, 今回の開発の目的である高速 $\mathrm{NO}_{\mathrm{x}}$ 測定を行うためには, サン プリング系の内容積ができるだけ小さく，かつ多くのサンプルガ ス流量が確保でき, 効率の良い連続使用可能なダスト除去システ ムを選択することが必要になる。ささらに, 測定に影響する他のが スが発生しないもの（例之ば EP はオゾンガスの発生が愻念され る）を選ぶ必要がある。その結果，今回の開発では，Fig.6に示す 垂直型の小型サイクロンを選定した.

小型サイクロンの設計には, 井伊谷らの研究から (Iinoya, 1977), 最適標準形サイクロンの各部寸法を参考にした. 設計した 小型サイクロンは, サンプルガスの入口/出口部, サイクロン部, ダスト沈降部および空気エゼクタ部で構成されている。ここで, 空気エゼク夕部はサイクロン部で捕集したダストの吸引と目詰ま り防止のパージ機構を持っており, 排出したダストは煙道内へ自 動的に回収される構造になっている.

\section{3 パージフィルタの改良}

従来のパージフィル夕を Fig. 7(a) に示す. 従来のパージフィ ル夕は, サンプルガス流量 $Q$ を $3 \mathrm{l} / \mathrm{min}$ で使用し, 目詰まり防止 のため 2 3 回/日の頻度で逆洗を行っていた. 改良型パージフィ ルタでは, この逆洗回数を従来と同じ程度とし, サンプルガスの 応答時間を短縮するため, Fig. 7 (b)に示すように長円筒形の構造 とし, 従来品と同じ沪過面積を確保しながら,容積を約 $1 / 2$ 程度と

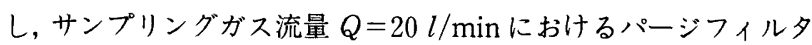
のみの $90 \%$ 応答時間 $T_{90}^{\prime}$ を $7.5 \mathrm{sec}$ から $3.0 \mathrm{sec}$ に短縮するこ とができた。

\section{5. 模擬石炭排ガスサンプルによる実験結果}

\section{1 ダスト除去効果}

本研究のダスト除去効果の基礎試験は, Fig. 8 に示すように, 中 


\begin{tabular}{|c|c|c|}
\hline $\begin{array}{l}\text { Rinds of } \\
\text { purge filters }\end{array}$ & $\begin{array}{l}\text { (a) Conventional } \\
\text { purge filter }\end{array}$ & $\begin{array}{l}\text { (b) Advanced } \\
\text { purge filter }\end{array}$ \\
\hline Filtration area & $270 \mathrm{~cm}^{2}$ & $270 \mathrm{~cm}^{2}$ \\
\hline $\begin{array}{l}\text { Inner volume } \\
\text { of filter }\end{array}$ & $1,150 \mathrm{~cm}^{3}$ & $470 \mathrm{~cm}^{3}$ \\
\hline $\begin{array}{c}\text { Delay-time value } \\
T_{90}^{\prime} \\
t_{90}^{\prime} \\
t^{\prime} d\end{array}$ & $\begin{array}{l}7.5 \mathrm{sec} \\
4.0 \mathrm{sec} \\
3.5 \mathrm{sec}\end{array}$ & $\begin{array}{l}3.0 \mathrm{sec} \\
1.6 \mathrm{sec} \\
1.4 \mathrm{sec}\end{array}$ \\
\hline Configuration & $\begin{array}{c}\text { Gas outlet } \\
(0=201 / \mathrm{min})\end{array}$ & $\left.\right|^{(0=201 / \mathrm{min})}$ \\
\hline & Gas inlet & Gas inlet \\
\hline
\end{tabular}

Fig. 7 Configuration of purge type filters

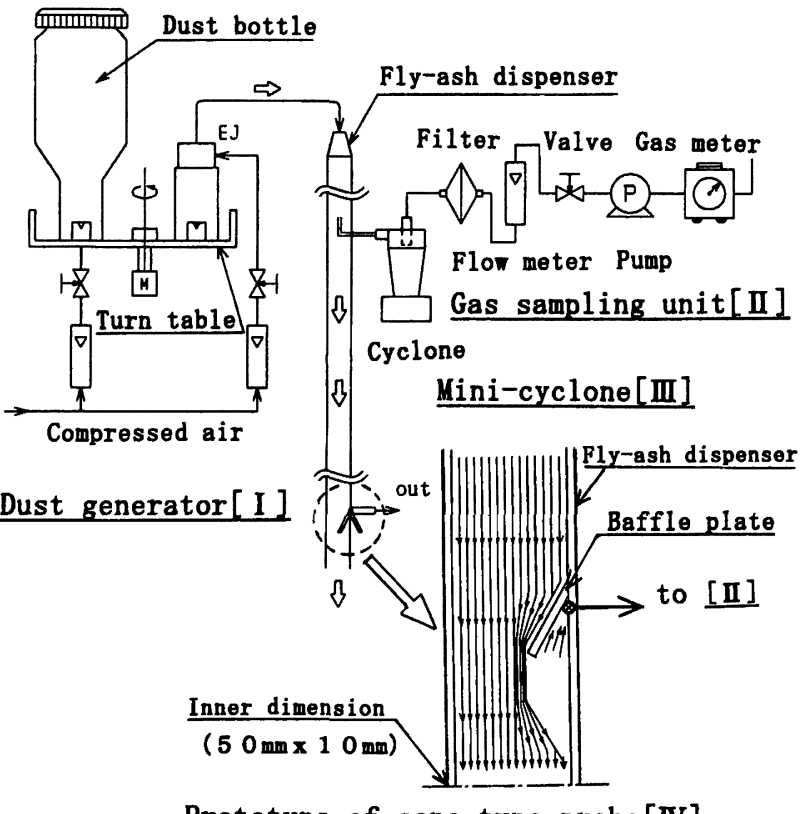

Prototype of cone type probe[IV]

Fig. 8 Schematic diagram of experimental apparatus

国電力（株）水島発電所 1 号機のフライアッシュ（密度 $2.19 \mathrm{~g}$ / $\mathrm{cm}^{3}$, 粒子径範囲 $D 1.73 \sim 300.3 \mu \mathrm{m}$ およびメヂアン径 $D_{\mathrm{m}} 30.2 \mu$ m)を使用して, ダストジェネレータ（I）(柴田科学製, DF-5 型) によりダスト濃度 $C_{0}$ 約 $20 \mathrm{~g} / \mathrm{m}^{3}$, 流量 $100 \mathrm{l} / \mathrm{min}$ の模擬石炭排ガ スを発生させて行った. 試験はコーン型プローブ, 小型サイクロ ンについて, それぞれ各装置の出口のダスト濃度 $C_{\mathrm{m}}$ をガスサン プリングユニット（II）のフィルタにより捕集したダストの重さ と流量から算出し，ダスト除去率 $\eta を \eta=\left(1-C_{\mathrm{m}} / C_{0}\right) \times 100(\%)$ により求めた。さらにコーン型プローブおよび小型サイクロンに おけるダストの捕集状況を確認するため, 捕集したダストの粒度 分布特性を粒度分布測定装置（堀場製 LA-920 型）により测定し，
Table 1 Particle separation efficiency of cone type probe (proto-type)

\begin{tabular}{cc}
\hline $\begin{array}{c}\text { Sampling gas flow-rate } \\
(l / \mathrm{min})\end{array}$ & $\begin{array}{c}\text { Particle separation } \\
\text { efficiency } \\
(\eta \%), n=2\end{array}$ \\
\hline 0.5 & 96.6 \\
& 97.0 \\
\hline \multirow{2}{*}{1.0} & 95.5 \\
& 95.8 \\
\hline
\end{tabular}

Table 2 Particle separation efficiency of mini-cyclone

\begin{tabular}{|c|c|c|}
\hline \multicolumn{2}{|c|}{ Condition at cyclone inlet } & \multirow{2}{*}{$\begin{array}{l}\text { Particle } \\
\text { separation } \\
\text { efficiency } \\
\qquad(\eta \%)\end{array}$} \\
\hline $\begin{array}{c}\text { Flow-rate } \\
(\mathrm{l} / \mathrm{min})\end{array}$ & $\begin{array}{c}\text { Temperature } \\
\text { of test gas } \\
\left({ }^{\circ} \mathrm{C}\right)\end{array}$ & \\
\hline 15 & 30 & 95.1 \\
\hline 20 & 30 & 95.9 \\
\hline$* 20$ & 30 & 98.5 \\
\hline 25 & 30 & 96.3 \\
\hline 20 & 85 & 96.8 \\
\hline 20 & 130 & 96.7 \\
\hline
\end{tabular}

* Two mini-cyclones are used in series

Dust concentration $C_{0} ; 20 \mathrm{~g} / l$ (fly-ash)

メヂアン径 $D_{\mathrm{m}}$ の変化を確認した．以下にその結果を述べる.

5.1.1 コーン型プローブによる効果Ｆig.5(b) に示すコー ン型プローブのプロトタイプ (IV) を実験システム Fig. 8 のアク リル製ダスト分配管にセットして，2 種類のサンプルガス流量条 件にてダスト除去率 $\eta$ を測定した。

この結果, 分配管のダスト濃度 $\mathrm{C}_{0}$ 約 $20 \mathrm{~g} / \mathrm{m}^{3}$, サンプルガス流 量 $Q 0.5 \mathrm{l} / \mathrm{min}, 1 \mathrm{l} / \mathrm{min}$ という条件で(この実験は実験機器の制 約から, 実用機の $1 / 20$ の大きさのサンプリングプローブを使って 行っており，そのためサンプリング流量は $0.5 \mathrm{l} / \mathrm{min}, 1 \mathrm{l} / \mathrm{min}$ と している), Table 1 に示すようにダスト除去率 $\eta 95 \%$ 程度以上 が得られることを確認した。

5.1 .2 小型サイクロンによる効果 Fig.6の小型サイクロ ンを実験システムFig. 8の（III）にセットして，いくつかのサン プリング条件にてダスト除去率を測定した。この結果, ダスト濃 度 $C_{0}$ 約 $20 \mathrm{~g} / \mathrm{m}^{3}$, サンプルガス流量 $Q 15 \mathrm{l} / \mathrm{min}, 20 \mathrm{l} / \mathrm{min}, 25 \mathrm{l} /$ min という条件で, Table 2 に示すように, 小型サイクロン 1 段の 時はダスト除去率 $\eta 95.0 \%$ 程度以上, サンプリングガス流量 $Q$ $20 \mathrm{l} / \mathrm{min}$ にて小型サイクロンを 2 段重ねた時は, ダスト除去率 $\eta$ 98.5\% が得られることを確認した. また，サイクロンの捕集ダス トと出ロダストの粒度分布特性の測定結果を Fig. 9に示す.これ らの結果から，コーン型プローブおよび小型サイクロンにおいて， 粒径の大きなダストが除去できていることを確認した。

\section{2 応答速度の向上}

石炭焚発電プラント用高速 $\mathrm{NO}_{\mathrm{x}}$ 測定装置（Fig. 2 (b) 参照）の サンプリングプローブ出ロ部から校正ガスを吸引させ, 応答速度 $T_{90}$ を確認した結果, Fig. 10 に示すように従来の $\mathrm{NO}_{\mathrm{x}}$ 測定装置 に比べ $T_{90}$ は約 $1 / 9$ となり，110 sec 早いことを確認した。

\section{6. 実機試験結果}

実機試験を水島発電所 1 号機（石炭焚発電プラント $125 \mathrm{MW}$, 以下水島 NO. 1 U と略称する）および下関発電所 1 号機（石炭焚 発電プラント $175 \mathrm{MW}$ ，以下下関 NO. $1 \mathrm{U}$ とする) の 2 プラント 


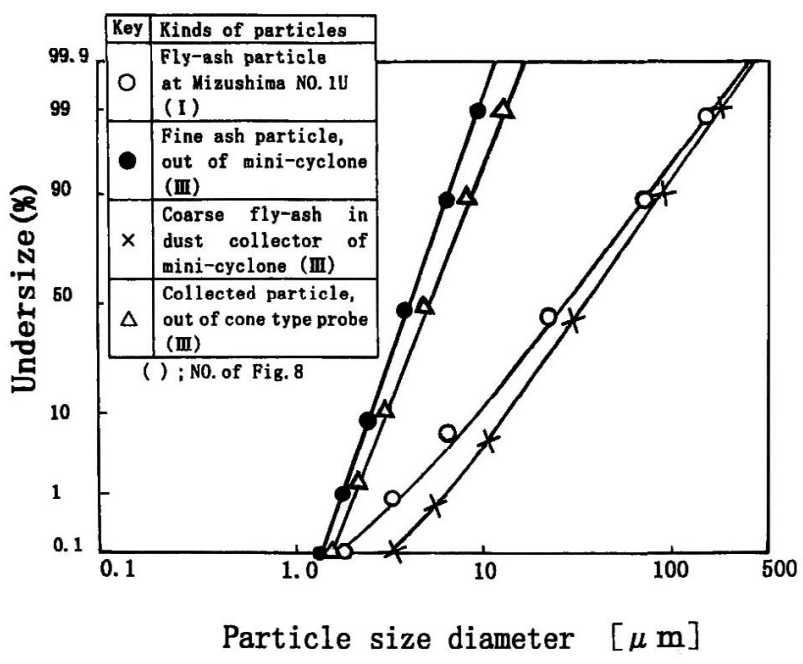

Fig. 9 Particle distribution of various particles

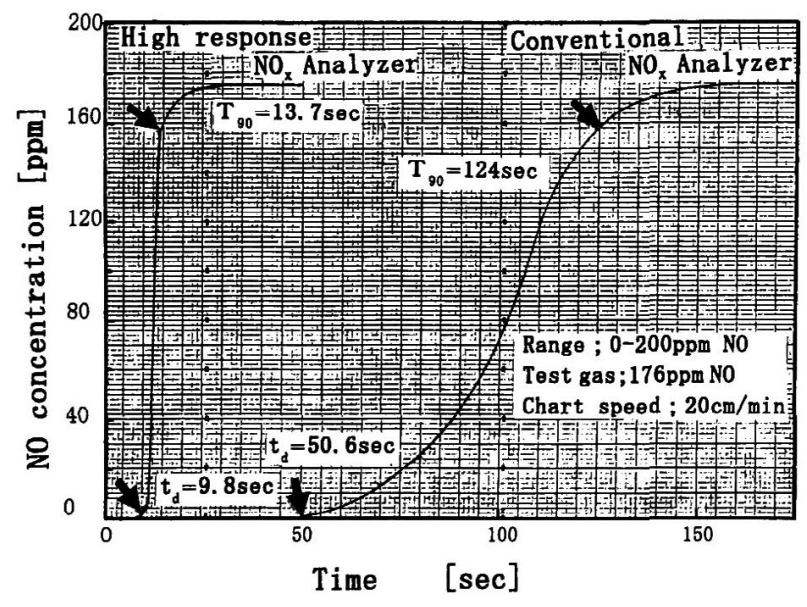

Fig. 10 Response time of $\mathrm{NO}_{\mathrm{x}}$ analyzers

で実施した. 排ガス中ダスト濃度 $C_{0}$ の測定は, 脱硝装置上流側の 既設 $\mathrm{NO}_{\mathrm{x}}$ 測定装置のガス採取点に近接のフランジポートを使用 した.

Fig. 11 および Fig. 12 に主要機器の外観写真を示す.

\section{1 ダスト除去システムの効果}

ダスト除去システムのダスト除去率を测定するために, JIS $Z 8808$ 規格に基づき, 水島 NO. $1 \mathrm{U}$ および下関 NO. $1 \mathrm{U}$ のダスト 浱度 $C_{0}$ を測定した. その結果, 水島 NO. $1 \mathrm{U}$ の排がス中のダスト 濃度 $C_{0}$ は平均 $19.5 \mathrm{~g} / \mathrm{m}^{3}(\mathrm{n}=5$, 最小 $=17.1$, 最大 $=22.4)$, 下関 NO. $1 \mathrm{U}$ の $C_{0}$ は平均 $25.9 \mathrm{~g} / \mathrm{m}^{3}(\mathrm{n}=5$, 最小 $=20.3$, 最大 $=31.6)$ であった。

下関 NO. $1 \mathrm{U}$ の $C_{0}$ はやや高いが, 水島 NO. $1 \mathrm{U}$ は石炭焚火力 発電所の平均的な值である.

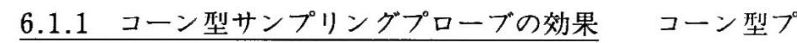
ローブ出口のダスト浱度 $C_{\mathrm{m}}$ を測定して，実機における排ガス中 ダスト濃度に対するダスト除去効果を確認した。水島 NO. $1 \mathrm{U}$ で は $94.0 \%$ ，下関NO. 1 Uは $96.8 \%$ のダスト除去率クを得た。こ れは基整実験で得たダスト除去率 $\eta=95.0 \%$ の結果に近似して おり，計画どおりの性能があることを確認した。

6.1.2 小型サイクロンによる効果小型サイクロン入口お よび出口のダスト濃度よりダスト除去効果を確認した結果, 水島 NO. 1 Uでは 93.5\% でやや低いが下関 NO. 1 Uでは $97.1 \%$ の ダスト除去率を得た. 実機試験機では小型サイクロンは高いダス

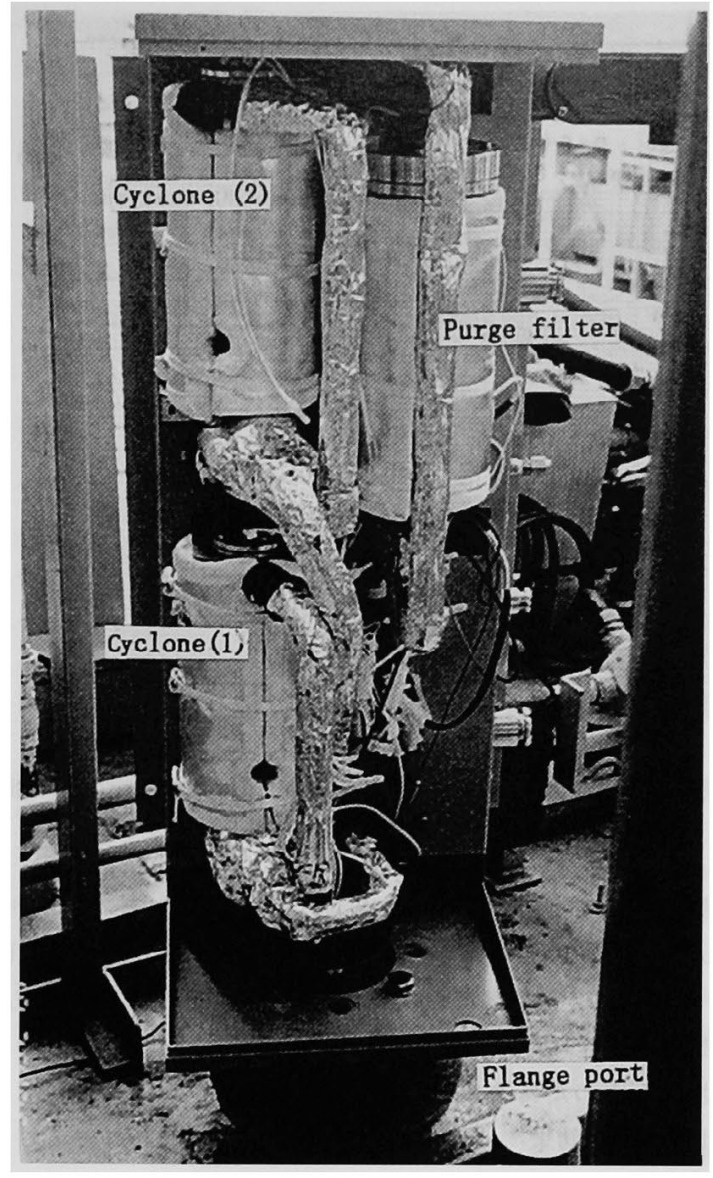

Fig. 11 Picture of dust removal system

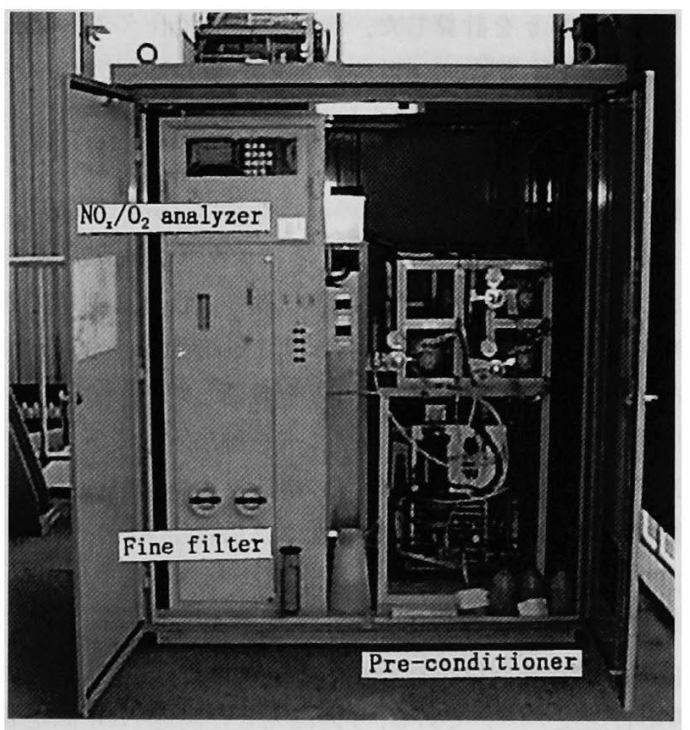

Fig. 12 Picture of $\mathrm{NO}_{\mathrm{x}}$ analyzer and pre-conditioner

卜除去率を得るために 2 段使用しており，両者の結果は小型サイ クロン 2 段使用時の基整実験デ一タ ク $98.5 \%$ に比べて低く，また 下関 NO. $1 \mathrm{U}$ の結果は，小型サイクロン 1段使用時の基礎デー夕 $\eta 95 \%$ 程度以上に比へてもも低いが，これはコーン型プローブで既 にダストの多くが除去されており，入口檂度 $C_{\mathrm{m}}$ が低くなること が原因と考えられる。

6.1 .3 改良型パージフィルタの効果パージフィルタの目 詰まりの程度は，フィルタ前後における圧力差 $\Delta P$ (Fig. 2(b) の 圧力センサにて検出）で測ることができ，逆洗前後において $\Delta P$ 


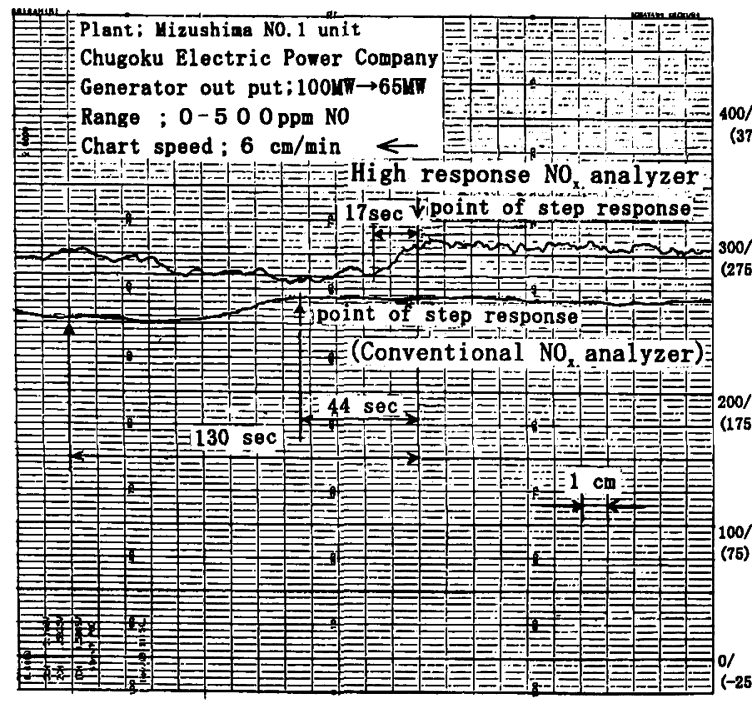

Fig. 13 Step response of $\mathrm{NO}_{\mathbf{x}}$ analyzers after generator output changing

は長期にわたり安定に維持されることが必要である。試験中 $\Delta P$ は, 水島 NO. 1 Uで $3.0 \sim 3.5 \mathrm{kPa}$ および下関 NO. 1 Uで $4.0 \sim 4.5 \mathrm{kPa}$ で推移しており, パージフィル夕の逆洗効果が連続 して得られ安定に動作していることを確認した。なお両者のフィ ルタ出口圧力の差異はダスト濃度 $C_{0}$ の違いである.

6.1 .4 総合効果 前項で得られたコーン型プローブおよび 小型サイクロンのダスト除去率の測定結果から，コーン型プロー ブ入口から $\mathrm{NO}_{\mathrm{x}}$ 測定装置入口までのサンプリング系全体での総 合ダスト除去率 $\eta$ を計算した。その結果，総合ダスト除去効率 は，水島 NO. 1 Uでは 99.6\%，また下関 NO. 1 Uでは 99.9\% が 得られ，十分に高い総合ダスト除去率が得られていることを確認 した.

実機試験中のパージフィルタの逆洗操作は 2 回/日実施し, サン プリングポンプも安定に動作しサンプルガス流量が常時安定で あったことから，本システムは正常に動作できたと判断できる。 水島 NO. 1 U で約 6 ヶ月間, 下関 NO. 1 Uで約 1 个月間それぞれ 連続試験を行ない実用に供することを確認した。

この間，小型サイクロンからダストを排出する空気エゼクタの 詰まりがあったが, 空気エゼクタの構造を水平型から Fig. 6 に示 す垂直型へ改良したことおよびエゼク夕供給空気圧（流量）を調 整したこと等で解決した.

\section{2 応答性能および検出感度}

Fig. 13 は, 水島 NO. $1 \mathrm{U}$ のボイラ負荷変動時における $\mathrm{NO}_{\mathrm{x}}$ 測 定值の応答速度データである.今回開発した高速 $\mathrm{NO}_{\mathrm{x}}$ 測定装置の 場合は指示変化開始後 $17 \mathrm{sec}$ で安定值を示すが, 既設 $\mathrm{NO}_{\mathbf{x}}$ 測定 装置は $44 \mathrm{sec} て ゙$ 指示変化が始まり安定化までに $130 \mathrm{sec}$ を要して いる.ここで高速 $\mathrm{NO}_{\mathrm{x}}$ 測定装置の実機試験における測定結果が模 擬石炭排ガスによる実験結果に比べ指示安定化まで $17 \mathrm{sec}$ と長 時間を要しているのは, 模擬石炭排ガスによる測定ではサンプリ ングプローブ出ロ部から応答時間を測定していたのに対して, 実 機試験ではサンプリングプローブ入口から応答時間を測定してお ク, サンプリングプローブの容積分だけ応答時間が遅くなってい るため, さらには実際にボイラで発生する $\mathrm{NO}_{\mathrm{x}}$ が模擬石炭排がス による実験とは異なりゆるやかに変化しているためと考えられる。 また，短時間の $\mathrm{NO}_{\mathrm{x}}$ 応答変化を見ると既設 $\mathrm{NO}_{\mathrm{x}}$ 测定装置では (a) Trend chart of conventional $\mathrm{NO}_{\mathrm{x}}$ analyzer

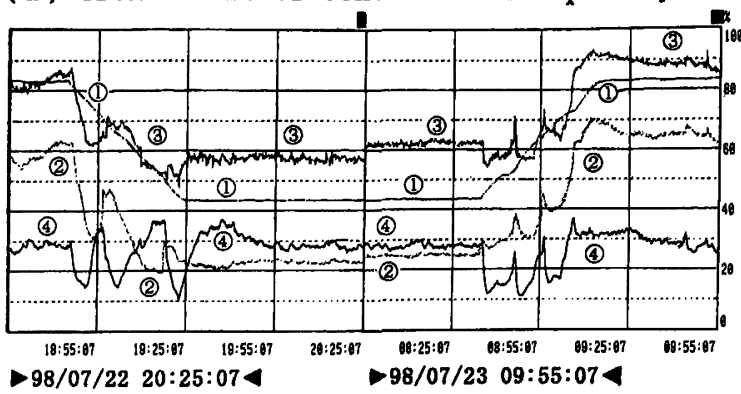

(b) Trend chart of high response $\mathrm{NO}_{\mathrm{x}}$ analyzer

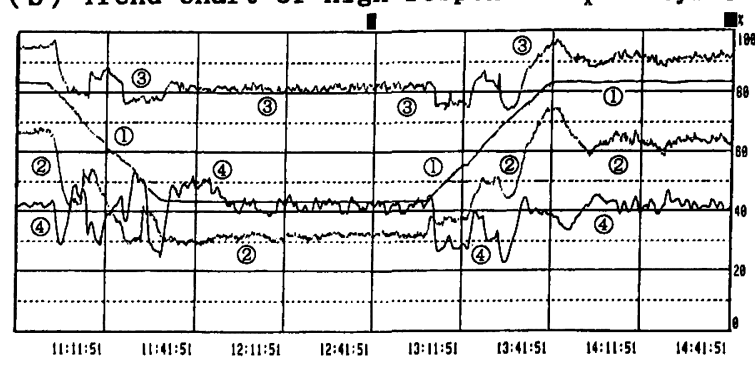

$\rightarrow 97 / 02 / 2612: 41: 514>97 / 02 / 2614: 41: 51<$

\begin{tabular}{|l|l|l|l|l|l|}
\hline No & Signal name & Units & NO & Signal name & Units \\
\hline
\end{tabular}

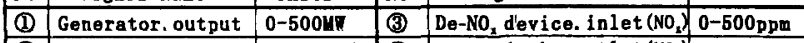

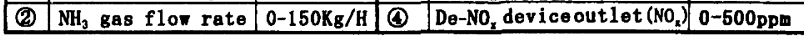

Fig. 14 Comparison of operation data of de-NOx device by using conventional $\mathrm{NO}_{\mathrm{x}}$ analyzer and high response $\mathrm{NO}_{\mathrm{x}}$ analyzer at Mizushima NO. 1 unit

負荷一定時に $\mathrm{NO}_{\mathrm{x}}$ 変化をほとんど検出できなかったのに対し, 高 速 $\mathrm{NO}_{\mathrm{x}}$ 測定装置では, $5 \sim 15 \mathrm{sec}$ の周期で変化する変化幅 $3 \sim 4$ $\mathrm{ppm} の \mathrm{NO}_{\mathrm{x}}$ を検出することができた。

\section{3 測定データの精度維持}

今回開発した $\mathrm{NO}_{\mathrm{x}}$ 測定装置と既設 $\mathrm{NO}_{\mathrm{x}}$ 測定装置の測定デー夕 を比較し，その相関係数 $r$ を求めた。

この結果, 水島 $\mathrm{NO} .1 \mathrm{U}$ の開発高速 $\mathrm{NO}_{\mathrm{x}}$ 测定装置と既設 $\mathrm{NO}_{\mathrm{x}}$ 測定装置は濃度範囲 $140 \mathrm{ppm} \sim 210 \mathrm{ppm}$ におて $r=$ $0.9886(n=44)$, 下関 NO. 1 U では濃度範囲 $420 \mathrm{ppm} \sim 650 \mathrm{ppm}$ にて $r=0.9984(n=31)$ と非常に高い相関が得られ，従来機種と 同程度の精度を維持していることを確認した。

\section{4 石炭焚発電プラントへの適用評価}

水島 NO. $1 \mathrm{U}$ の脱硝装置入口及び出口に高速 $\mathrm{NO}_{\mathrm{x}}$ 測定装置を 設置して, 実際の運転に適用した. 高速 $\mathrm{NO}_{\mathrm{x}}$ 測定装置取付前後に おける脱硝装置の制御性を比較したトレンドチャートを Fig. 14 に示す. Table 3 はこの適用効果を解析し, 比較表にまとめたもの である。

6.4 .1 負荷一定時 脱硝入口の $\mathrm{NO}_{\mathrm{x}}$ 測定值は Fig. 13 に示 すように, 5 15 sec の周期で変化する変化幅 3〜 $4 \mathrm{ppm} の \mathrm{NO}_{\mathrm{x}}$ の検出により, 排ガス中 $\mathrm{NO}_{\mathrm{x}}$ 濃度変化に対する追従性が改善され た. その結果, Fig. 14（a）に示すように，ボイラの運転状態によ る $\mathrm{NO}_{\mathrm{x}}$ 量の変化に対してアンモニア注入量が速応制御されて脱 硝装置出口 $\mathrm{NO}_{\mathrm{x}}$ 值の変化幅が少なくなった.

6.4 .2 負荷変化時 負荷変化開始後の脱硝入口及び出口 $\mathrm{NO}_{\mathrm{x}}$ 測定値の追従性は早いが，ボイラの運転状態が大きく変化す る場合は脱硝装置本体に 7 分程度の反応遅れがあり, 負荷上昇お よび下降時の脱硝装置出口 $\mathrm{NO}_{\mathrm{x}}$ 值の変動幅は小さくなったが顕 著な改善はできていない. しかし, 出入口 $\mathrm{NO}_{\mathrm{x}}$ 測定值の検出測定 が早いので適応制御と組み合わせた負荷変化時の改善が期待でき 
Table 3 Evaluation of operation of de- NOx device by using conventional $\mathrm{NO}_{x}$ analyzer and high response $\mathrm{NO}_{x}$ analyzer at Mizushima NO. 1 unit

\begin{tabular}{|c|c|c|c|c|}
\hline $\begin{array}{l}\text { Modes of } \\
\text { operation }\end{array}$ & \multicolumn{2}{|c|}{$\begin{array}{l}\text { Items of } \\
\text { evaluation }\end{array}$} & $\begin{array}{l}\text { Conventional } \\
\mathrm{NO}_{\mathrm{x}} \text { analyzer }\end{array}$ & $\begin{array}{l}\text { High response } \\
\text { NO }_{x} \text { analyzer }\end{array}$ \\
\hline \multirow{4}{*}{$\begin{array}{l}\text { Constant load } \\
(63 \text { and } 125 \mathrm{MW})\end{array}$} & \multirow{2}{*}{$\begin{array}{r}\text { Inlet }\left(\mathrm{NO}_{\mathrm{x}}\right) \\
\text { values }\end{array}$} & $t_{\mathrm{d} 1}$ & $2 \mathrm{~min} 15 \mathrm{sec}$ & $1 \mathrm{~min}$ \\
\hline & & $\Delta C$ & $15 \mathrm{ppm}$ & $25 \mathrm{ppm}$ \\
\hline & \multirow{2}{*}{$\begin{array}{r}\text { Outlet }\left(\mathrm{NO}_{\mathbf{x}}\right) \\
\text { values }\end{array}$} & $t_{\mathrm{d} 1}$ & $2 \mathrm{~min} \quad 45 \mathrm{sec}$ & $1 \mathrm{~min}$ \\
\hline & & $\Delta C$ & $15.8 \mathrm{ppm}$ & $8.8 \mathrm{ppm}$ \\
\hline \multirow{4}{*}{$\begin{array}{l}\text { During load changes } \\
(125 \mathrm{MW} \rightarrow 63 \mathrm{MW} / \\
63 \mathrm{MW} \rightarrow 125 \mathrm{MW})\end{array}$} & \multirow{2}{*}{$\begin{array}{r}\text { Inlet }\left(\mathrm{NO}_{\mathrm{x}}\right) \\
\text { values }\end{array}$} & $t_{\mathrm{d} 2}$ & $8 \mathrm{~min}$ & $2 \mathrm{~min} 45 \mathrm{sec}$ \\
\hline & & $\Delta C$ & $52.5 \mathrm{ppm}$ & $48.4 \mathrm{ppm}$ \\
\hline & \multirow{2}{*}{$\begin{array}{r}\text { Outlet }\left(\mathrm{NO}_{\mathrm{x}}\right) \\
\text { values }\end{array}$} & $t_{\mathrm{d} 2}$ & $21 \mathrm{~min} 30 \mathrm{sec}$ & $16 \mathrm{~min} 30 \mathrm{sec}$ \\
\hline & & $\Delta C$ & $63.2 \mathrm{ppm}$ & $61.0 \mathrm{ppm}$ \\
\hline
\end{tabular}

る.

以上の実プラントの適応結果と, 現在の石炭焚発電プラントは 主に負荷一定運転を行っていることから, 開発した石炭焚発電プ ラント用高速 $\mathrm{NO}_{\mathrm{x}}$ 測定装置は脱硝装置の効率的な運用や運転制 御の安定化に寄与することがわかった。

\section{結言}

石炭焚発電プラント用高速 $\mathrm{NO}_{\mathrm{x}}$ 測定装置の開発にあたり, 高速 $\mathrm{NO}_{\mathrm{x}}$ 測定に必要な多量のサンプルガス流量を確保でき，かつ石炭 焚燃焼排ガス中に含まれるダストを十分に除去できるダスト除去 システムを開発した.その結果, 従来の約 $1 / 9$ という応答時間を持 った高速 $\mathrm{NO}_{\mathrm{x}}$ 測定装置を開発することができ, 実際の石炭焚発電 プラントへ適用したところ, 脱硝装置の効率的な運用や運転制御 の安定化に寄与することができた。

今回開発したダスト除去システムは，可動部も少なく，実用的 なサンプリングコンポーネントであり,さらには $\mathrm{NO}_{\mathrm{x}}$ 測定装置以 外の排ガス分析用サンプリングシステムとして，現在建設中の石

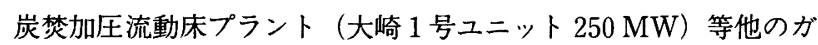
ス成分 $\left(\mathrm{SO}_{2}\right.$ や $\mathrm{NH}_{3}$ 等) の測定への適用が期待できる。

また, 開発した石炭焚発電プラント用高速 $\mathrm{NO}_{\mathrm{x}}$ 測定装置は, 実 用機としては, 水島 NO. $1 \mathrm{U}$ の他三隅 NO. $1 \mathrm{U}$ (石炭焚発電プラ ント $1,000 \mathrm{MW}$, 平成 10 年 6 月より営業試運転開始), 新小野田 NO. $2 \mathrm{U}$ (石炭焚発電プラント $500 \mathrm{MW}$, 平成 10 年 9 月より高速 $\mathrm{NO}_{\mathrm{x}}$ 測定装置が稼動) の脱硝装置において採用され，効率的な運 用や運転制御の安定化に貢献し，発電所の環境保全の一翼を担 なっている. そして現在, 新小野田 NO. 2 Uにて高速 $\mathrm{NO}_{\mathrm{x}}$ 測定装 置とファジィ制御を組み合わせた負荷変化時の脱硝制御特性改善 策を実施中であり，今後とも改善，改良を加えていきたい。

[謝 辞] 本研究に際して，いろいろご協力頂いた中国電力株式会社 および株式会社堀場製作所の関係者に感謝の意を表す。

\section{Nomenclature}

$C_{0}=$ particle concentration of main flow or flue gas $\left[\mathrm{g} / \mathrm{m}^{3}\right]$
$C_{\mathrm{m}}=$ measured particle concentration

$\left[\mathrm{g} / \mathrm{m}^{3}\right]$

$D$ =diameter size of particle

$D_{\mathrm{m}}=$ median diameter of particle

$[\mu \mathrm{m}]$

$[\mu \mathrm{m}]$

$M W=$ generated electric power

[MW]

$n$ =number of measuring

$P \quad=$ pressure of flue gas

$Q \quad=$ gas sampling flow-rate

$[-]$

$[\mathrm{kPa}]$

$r=$ correlation coefficient

$[l / \mathrm{min}]$

[- ]

$t=$ the time required to replaced the volume of sampling components with gas

[sec]

$T_{90}=$ the time elapsed from the moment of introducing test gas to the moment of $90 \%$ value of the final indicated value, for sampling components, same as $t_{\mathrm{d}}+t_{90} \quad$ [sec]

$t_{90}=$ the time elapsed from the moment of first indicate value to the moment of $90 \%$ value of the final indicated value for sampling components

[sec]

$t_{\mathrm{d}}=$ dead time for response for sampling components [sec]

$t_{\mathrm{d} 1}=$ dead time of $\mathrm{NO}_{\mathrm{x}}$ measurements after changing generator output

[sec]

$t_{\mathrm{d} 2}=$ time-delay of $\mathrm{NO}_{\mathrm{x}}$ measurements after stabilizing genera tor output

[sec]

$T_{90}^{\prime}=$ the time elapsed from the moment of introducing test gas to the moment of $90 \%$ value of the final indicated value, for purge type filter, same as $t^{\prime}{ }_{\mathrm{d}}+t^{\prime}{ }_{90} \quad$ [sec]

$t^{\prime}{ }_{90}=$ the time elapsed from the moment of first indicated value to the moment of $90 \%$ value of the final indicated value for purge type filter
[sec]

$t^{\prime}{ }_{\mathrm{d}}=$ dead time for response for purge type filter [sec]

$u=$ velocity of flue gas $\quad[\mathrm{m} / \mathrm{sec}]$

$V=$ volume of sampling components $\left[\mathrm{m}^{3}\right]$

$\Delta C=$ fluctuation of $\mathrm{NO}_{\mathrm{x}}$ measurements $\quad[\mathrm{ppm}]$

$\Delta P=$ pressure drop of purge filter outlet after blow-back operation

$[\mathrm{kPa}]$

$\eta \quad=$ particle separation efficiency $\left(1-C_{\mathrm{m}} / C_{0}\right) \times 100$

\section{Literature cited}

Ando, J.; Technology of Total Flue Gas Treatment in the World, p. 134-158, Coal Technology Laboratory, Tokyo, Japan (1990)

Denki Gijutsu Kijun Chosa Iinkai ; Haien Dassho Setsubi Shishin, p. 13 -25, Nihon Denki Kyokai, Tokyo, Japan (1989)

Hirozane, T. and H. Kondo; "Operation Results of No. 2 Group at Yanai Power Station,” Karyoku Genshiryoku Hatsuden, 45, 521-527 (1994)

Iinoya, K. ; Shujin Souchi, $13^{\text {th }}$ Ed., p. 101-105, Nikkan Kogyo Shinbunsha, Tokyo, Japan (1973)

Iinoya, K. ; Shujin Souchi no Seino, 2 nd ed., p. 42-47, Sangyo Gijutsu Senta, Tokyo, Japan (1977)

Ito, S., T. Kawamura and S. Komura ; "Regeneration of Ceramic Filter Applied to Coal Char Separation," Kagaku Kogaku Ronbunshu, 21 265-271 (1995)

Makino, H., H. Tsuji, M. Kimoto, H. Yoshida and K. Inoya ; “New Estimation Method of Particle Size Distribution by Anisokinetic Sampling," Kagaku Kogaku Ronbunshu, 21, 896-903 (1995) 


\title{
Development of High Response NO Analyzer for Coal-fired Power Plants
}

\section{ISAO SHIROMARU ${ }^{1}$ and SHIGEYUKI AKIYAMA ${ }^{2}$}

\author{
${ }^{1}$ Thermal Power Technology Center, The Chugoku Electric Power Co., Inc., Ube 759-0205
}

${ }^{2}$ Quality Control Department, Horiba Ltd., Kyoto 601-8510

Key words: high response $\mathrm{NO}_{\mathrm{x}}$ analyzer, dust removal sampling, cone-type sampling probe, de$\mathrm{NO}_{\mathbf{x}}$ device control, coal-fired power plant.

In thermal power plants, the nitrogen oxides produced by the boilers are removed by de- $\mathrm{NO}_{\mathrm{x}}$ devices. For efficient operation of the de- $\mathrm{NO}_{x}$ device and stable control of the power plant, the speeding up of the response of the $\mathrm{NO}_{\mathrm{x}}$ analyzer in the flue gas is effective. In past research, we developed high response $\mathrm{NO}_{\mathrm{x}}$ analyzer for $\mathrm{LNG}$-fired power plants by using a technique of increasing sampling gas flow. However, for a coal-fired power plant, it was difficult to develop the high response $\mathrm{NO}_{\mathrm{x}}$ analyzer using the same technique as previous development, because the coal-fired flue gas contains much dust. In this research, we developed a high response $\mathrm{NO}_{\mathrm{x}}$ analyzer for coal-fired power plant with one-ninth the response time by development of a dust removal system, and this analyzer can maintain the high dust removal efficiency under the high volume sampling. Then, we applied this high response $\mathrm{NO}_{\mathrm{x}}$ analyzer to an actual coal-fired power plant, and we checked the performance of it. 